12 - ORIGINALARTICLE Experimental Urology

\title{
Metabolic programming of lipid profile and reproductive organs weight by leptin treatment on early life ${ }^{1}$
}

\author{
Programação metabólica do perfil lipídico e peso dos órgãos do sistema reprodutor pelo \\ tratamento com leptina nos primeiros dias de vida
}

\author{
Durval Santos Marques ${ }^{\mathrm{I}}$, Flávia Meireles Gombar ${ }^{\mathrm{II}}$, Jorge Luiz Alves Pereira ${ }^{\mathrm{III}}$. Francisco José Barcellos Sampaio ${ }^{\mathrm{IV}}$, Cristiane da \\ Fonte Ramos $v$
}

I Biologist, Urogenital Research Unit, UERJ, Rio de Janeiro, Brazil.
II Undergraduate Student, UERJ, Rio de Janeiro, Brazil.
III Technician, Urogenital Research Unit, UERJ, Rio de Janeiro, Brazil.
IV $\mathrm{PhD}$, Chairman and Head, Urogenital Research Unit, UERJ, Rio de Janeiro, Brazil.
${ }^{\text {V }} \mathrm{PhD}$, Associate Professor, Urogenital Research Unit, UERJ, Rio de Janeiro, Brazil.

\begin{abstract}
Purpose: To evaluate whether the neonatal leptin treatment during the first days of life can program the male reproductive organs weight and the lipid profile. Methods: At birth 6 dams were divided into 2 groups: Leptin - each pup was injected with $50 \mu \mathrm{L}$ of recombinant rat leptin $(80 \mathrm{ng} / \mathrm{g} \mathrm{BW}, \mathrm{sc})$, for the first $10 \mathrm{~d}$ of lactation; Control - each pup received the same volume of saline. After weaning, all pups received unlimited access to food until 190 days of age when they were killed. Values are given as mean \pm SEM of 6 animals and Test $t$ Student was used to analyze the results. Results: The leptin treatment resulted in a significant increase in body weight $($ Control= 411.8 \pm 16.31 ; Leptin= 481.8 \pm 11.29 , p=0.005) and food consumption (Control=25.32 \pm 0.09 ; Leptin= 32.42 \pm 0.15 , $\mathrm{p}=0.0001)$ and a significant reduction in triglycerides levels (Control $=540.0 \pm 117.9$; Leptin $=93.25 \pm 15.21, \mathrm{p}=0.006)$ and in the weight of hypothalamus $(\mathrm{Control}=$ $0.234 \pm 0.016$; Leptin $=0.154 \pm 0.015, \mathrm{p}=0.007)$, pituitary $($ Control $=0.104 \pm 0.0120$; Leptin $=0.033 \pm 0.012, \mathrm{p}=0.003)$, testis $($ Control $=3.75 \pm 0.055$; Leptin $=3.19 \pm 0.10, p=0.002)$ and prostate $($ Control $=1.641 \pm 0.1389$; Leptin $=0.91 \pm 0.07, p=0.001)$. Conclusion: Leptin treatment on the first days of life can program the reproductive organs weight and the lipid profile of the progeny.
\end{abstract}

Key words: Lactation. Leptin. Organ Size. Rats.

\section{RESUMO}

Objetivo: Avaliar se o tratamento neonatal com leptina durante os primeiros dias de vida poderia programar o peso dos orgãos do sistema reprodutor masculino e o perfil lipídico. Métodos: Ao nascimento seis ratas-mãe foram distribuídas em dois grupos: Leptina - cada filhote recebeu $50 \mu \mathrm{L}$ de leptina recombinante $(80 \mathrm{ng} / \mathrm{gPC}, \mathrm{SC})$ nos primeiros 10 dias de lactação; Controle - cada filhote recebeu o mesmo volume de salina. Após o desmame, todos os filhotes tiveram acesso ilimitado a ração até 190 dias de idade quando foram mortos. Os dados são expressos como média \pm erro padrão e foram analisados pelo teste t Student. Resultados: O tratamento com leptina resultou em aumento significativo no peso corporal (Control= 411.8 \pm 16.31 ; Leptin $=481.8 \pm 11.29, \mathrm{p}=0.005)$ e consumo alimentar $($ Control $=25.32 \pm 0.09$; Leptin= $32.42 \pm 0.15, \mathrm{p}=0.0001)$ e redução significativa nos níveis séricos de triglicerídeos (Control=540.0 $\pm 117.9 ;$ Leptin= $93.25 \pm 15.21$, $\mathrm{p}=0.006)$, no peso do hipotálamo $($ Control $=0.234 \pm 0.016$; Leptin $=0.154 \pm 0.015, \mathrm{p}=0.007)$, hipófise $($ Control $=0.104 \pm 0.0120 ;$ Leptin $=0.033 \pm 0.012, \mathrm{p}=0.003)$, testículo $($ Control $=3.75 \pm 0.055 ;$ Leptin $=3.19 \pm 0.10, \mathrm{p}=0.002)$ e próstata $($ Control=1.641 $\pm 0.1389 ;$ Leptin= $0.91 \pm 0.07$, $p=0.001)$. Conclusão: $\mathrm{O}$ tratamento com leptina nos primeiros dias de vida pode programar o peso dos órgãos do sistema reprodutor e o perfil lipídico da prole. Descritores: Lactação. Leptina. Tamanho do Órgão. Ratos.

${ }^{1}$ Research performed at Urogenital Research Unit, State University of Rio de Janeiro (UERJ), Brazil.

\section{Introduction}

Leptin is a $16 \mathrm{KDa}$ non-glycosylated polypeptide of 146 amino acids secreted by white adipocytes that plays a role in the regulation of body weight and food intake ${ }^{1}$. Leptin investigation has increased in many fields: the pathology of obesity, anorexia nervosa, diabetes mellitus, polycystic ovary syndrome, acquired immune disease, cancer, thyroid disease, nephropathy, Cushing's syndrome and growth hormone deficiency ${ }^{2}$.

The amount of body fat stored is known to influence fertility, indicating a link between adipose tissue and the reproductive system $^{3}$, but the exact mechanism connecting these processes is still not fully known. Both leptin deficiency and excess are associ- 
ated with reproductive abnormalities at both central and gonadal levels ${ }^{4,5}$.

Leptin acts by activating leptin receptors (OBRs). There are six known splice variants of OBR, all with the same extracellular domain, but with differing intracellular domains. The isoforms can be classified into three classes: short (OBRa, OBRc, OBRd, OBRf), long (OBRb) and secreted (OBRe). Only the isoform OBRb is considered to be capable of signal transduction across the cell membrane ${ }^{6}$.

The concept of metabolic programming is a permanent change related to a particular function, as a result of some event which occurs during the perinatal period ${ }^{7}$. Several animal experiments have shown that hormones as leptin and nutrition status, which affect development during sensitive periods early in life, permanently program the structure and function of body tissues and systems ${ }^{8-10}$.

Based on the fact that leptin abundance or deficiency contributes to the pathogenesis of reproductive abnormalities and that it can permanently program body systems and function, the aim of this study was to evaluate whether the neonatal leptin treatment during the first days of life can program the body and reproductive organs weight and the lipid profile.

\section{Methods}

The handling of animals was approved by the Animal Care and Use Committee of the Biology Institute of State University of Rio de Janeiro, which based their analysis on the Guide for the Care and Use of Laboratory Animals ${ }^{11}$. The study design was approved by the local Ethics Committee for the care and use of laboratory animals.

Wistar rats were kept in a room with controlled temperature $(25 \pm 10 \mathrm{C})$ and an artificial dark-light cycle (lights on from 7:00 to 19:00 h). Virgin female rats 3 months aged were caged with one male rat at a proportion of 2:1. After mating, determined by the presence of a vaginal plug, each female was placed in an individual cage with free access to water and food until delivery. Within 24 hours of birth, excess pups were removed so that only 6 pups were kept per dam, and were then divided into 2 groups:

Leptin group - each male pup was injected with $50 \mu \mathrm{L}$ of recombinant rat leptin (PeproTech, cat\#400-21) at a dose of 80ng/g $\mathrm{BW}, \mathrm{sc}$, for the first $10 \mathrm{~d}$ of lactation ${ }^{12}$.

Control group - each male pup received the same volume of saline $(0.9 \% \mathrm{NaCl})$ for the first $10 \mathrm{~d}$ of lactation. All the injections were made at 16.00 hours.

The pups of each group are from 3 different dams. After weaning, all pups received unlimited access to food and water until 190 days of age when they were killed with a lethal dose of thiopental and the hypothalamus, pituitary, bladder, testis, prostate and epididymis were dissected and weighted. The blood was collected by cardiac puncture and the serum kept at -20C for subsequent determination of triglycerides and cholesterol serum levels by colorimetric assay (bioclin). The body weight and food consumption were from birth until the end of experiment.

All results are expressed as mean \pm SEM. Statistical analysis was performed by Student's- $t$-test. Values of $p<0.05$ were considered significant.

\section{Results}

The leptin treated group body weight and food intake were significantly higher than the control group (Figure 1). In relation to the organs weight the leptin treated group presented a significant reduction at the hypothalamus, pituitary, testis and prostate. The reduction observed at the epididymis and bladder weights was not significant (Figure 2). The leptin treatment resulted in a significant decrease in triglycerides, without an alteration in the cholesterol serum levels (Figure 3).

hepatic cholesterol clearance. Am J Physiol Gastrointest Liver Physiol. 2001;281(2):G393-404

15. Prieur X, Tung YC, Griffin JL, Farooqi IS, O'Rahilly S, Coll AP. Leptin regulates peripheral lipid metabolism primarily through central effects on food intake. Endocrinology. 2008;149(11):5432-9.
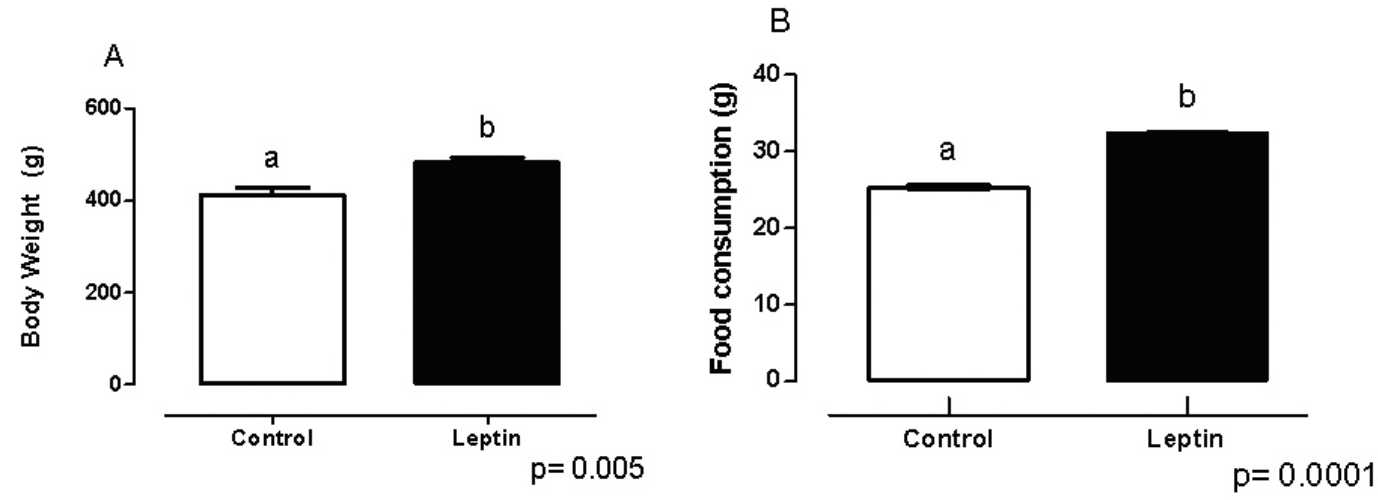

FIGURE 1 - Body weight (A) and food consumption (B) in control and leptin treated groups. Values are given as mean \pm SEM of 6 animals 

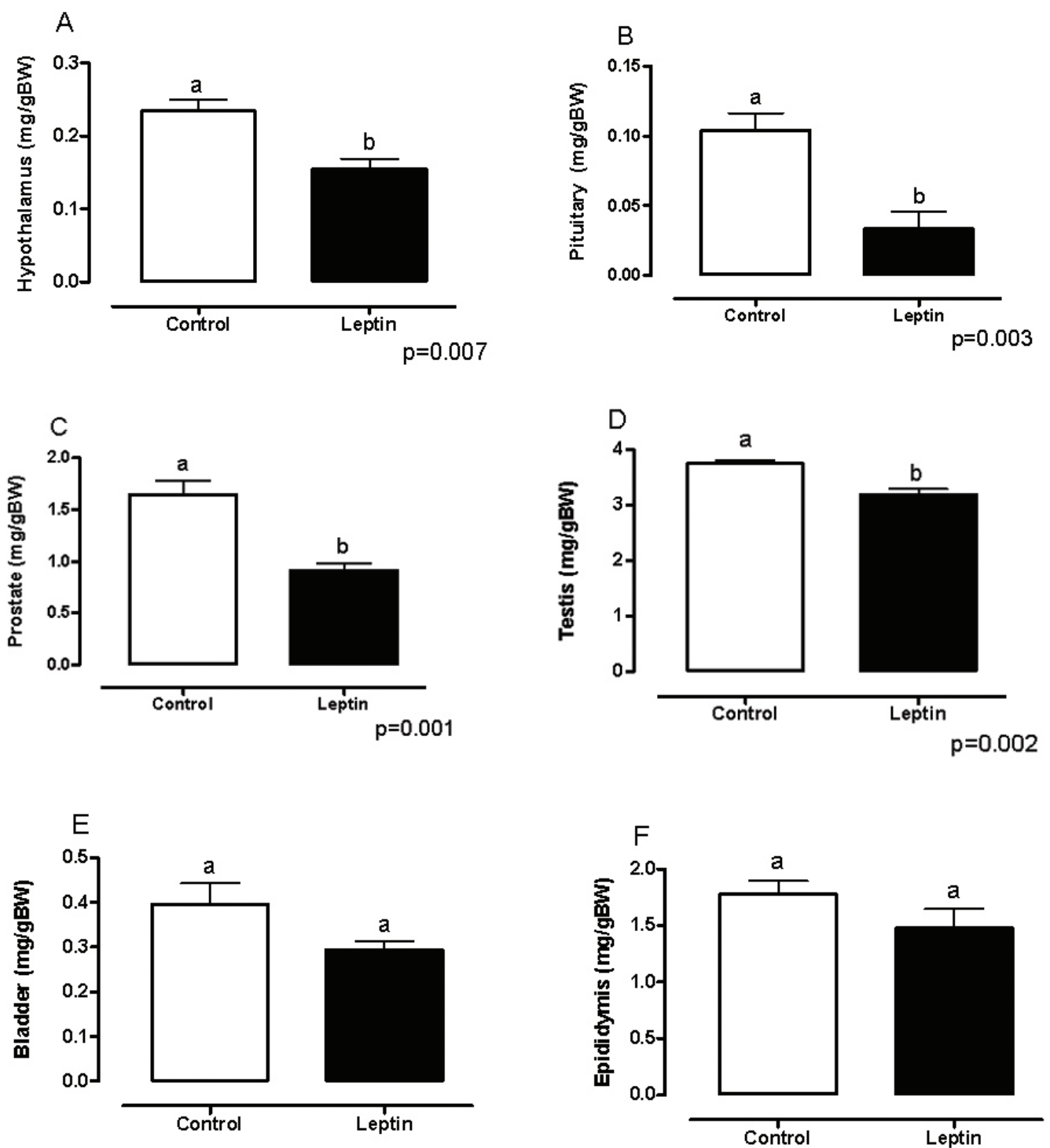

FIGURE 2 - (A) hypothalamus, $(\mathbf{B})$ pituitary, $(\mathbf{C})$ prostate, $(\mathbf{D})$ testis, $(\mathbf{E})$ bladder and $(\mathrm{F})$ epididymis weights in control and leptin treated groups. Values are given as mean \pm SEM of 6 animals
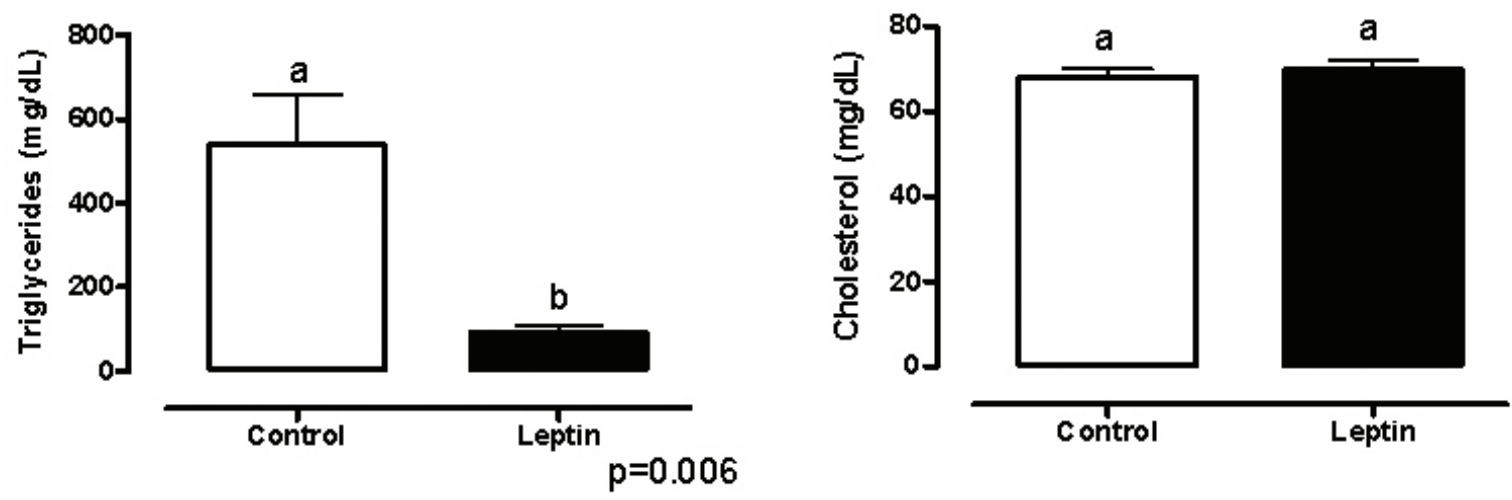

FIGURE 3 - Triglycerides and cholesterol serum levels in control and leptin treated groups. Values are given as mean \pm SEM of 6 animals 


\section{Discussion}

Several animal experiments have shown that hormones as leptin and nutrition status, which affect development during sensitive periods early in life, permanently program the structure and function of body tissues and systems ${ }^{8-10}$. The neonatal exposure to leptin is associated with higher food intake and adult body weight ${ }^{10}$. Our data are in agreement with those previous one, but despite the leptin treatment on early life had caused an overweight, the organs did not have the same weight increment suggesting that the body and organs weight can be programmed in a different way by leptin.

The long and fully functional isoform of the leptin receptor, OBRb, is expressed mainly in the hypothalamus, while the short isoforms are expressed in the peripheral tissues ${ }^{6}$. Possibly, the difference between the effect of leptin treatment on body and organs weight can be related with the widely expression of short isoforms of leptin receptors on the reproductive tissues.

A number of experiments have shown that leptin has a direct autocrine or paracrine mode of action on the rates of synthesis and degradation of lipids within adipose tissue as well as in other tissues that store triacylglycerol ${ }^{13-15}$. In summary, leptin has profound effects on peripheral lipid metabolism by downregulating cholesterol biosynthesis, upregulating cholesterol catabolism, promoting excess biliary cholesterol secretion, decreasing plasma very low-density lipoprotein (VLDL) cholesterol concentrations and decreasing plasma triglycerides and free fatty acid.

Based on those data we could expect that the leptin treatment would cause a decrease in triglycerides and an increase in cholesterol serum levels. However, many of the studies described in the literature have used in vitro or ex vivo preparations or adult animals treated with leptin for different period of time. So, it is difficult to place the data within the same physiological context. Since the animals were treated with leptin during the first days of life the results presented here can suggest that the lipid metabolism have been programmed by the leptin early in life.

\section{Conclusion}

Leptin treatment on the first days of life can program the reproductive organs weight and the lipid profile of the progeny.

\section{References}

1. Magni P, Motta M, Martini L. Leptin: a possible link between food intake, energy expenditure, and reproductive function. Regul Pept. 2000;92(1-3):51-6.

2. Frühbeck G, Jebb SA, Prentice AM. Leptin physiology and pathophysiology. Clin Physiol. 1998;18(5):399-419.

3. Frisch RE. The right weight: body fat, menarche and ovulation. Ballières Clin Gynaecol. 1990;4(3):419-39.

4. Chan JL, Matarese G, Shetty GK. Differential regulation of metabolic, neuroendocrine, and immune function by leptin in humans. Proc Natl Acad Sci USA. 2006;103(22):8481-6.

5. Farooqi S, Wangensteen T, Collins S. Clinical and molecular genetic spectrum of congenital deficiency of the leptin receptor. N Engl J Med. 2007;356(3):237-47.

6. Hegyi K, Fulop K, Kovacs K, Toth S, Falus A. Leptin-induced signal transduction pathways. Cell Biol Int. 2004;28:159-69.

7. Molina-Carballo A, Fernandez-Tardaguila E, Uberos-Fernandez J. Longitudinal study of the simultaneous secretion of melatonin and leptin duringnormal puberty. Horm Res. 2007;68:11-9.

8. Fischbeck KL, Rasmussen KM. Effect of repeated reproductive cycles on maternal nutritional status, lactational performance and litter growth in ad libitum-fed and chronically food-restricted rats, J Nutr. 1987;117(11):1967-75

9. Dörner G, Plagemann A. A Perinatal hyperinsulinism as possible predisposing factor for diabetes mellitus, obesity and enhanced cardiovascular risk in later life. Horm Metab Res. 1994;26(5):213-21.

10. Cravo CO, Teixeira CV, Passos MC, Dutra SC, Moura EG, Ramos C. Leptin treatment during the neonatal period is associated with higher food intake and adult body weight in rats. Horm Metab Res. 2002;34(7):400-

11. Bayne K. Revised guide for the care and use of laboratory animals available. Am Phys Soc Physiol. 1996;39(4):199:208-11.

12. Malendowicz LK, Macchi C, Nussdorfer GG, Nowak KW.- Acute effects of recombinant murine leptin on rat pituitary-adrenocortical function. Endocr Res. 1998;24(2):235-46.

13. Reidy SP, Weber J. Leptin: an essential regulator of lipid metabolism. Comp Biochem Physiol A Mol Integr Physiol. 2000;125(3):285-98.

14. VanPatten S, Ranginani N, Shefer S, Nguyen LB, Rossetti L, Cohen DE. Impaired biliary lipid secretion in obese Zucker rats: leptin promotes hepatic cholesterol clearance. Am J Physiol Gastrointest Liver Physiol. 2001;281(2):G393-404

15. Prieur X, Tung YC, Griffin JL, Farooqi IS, O'Rahilly S, Coll AP. Leptin regulates peripheral lipid metabolism primarily through central effects on food intake. Endocrinology. 2008;149(11):5432-9.

\section{Correspondence:}

Dr. Cristiane da Fonte Ramos

Urogenital Research Unit - UERJ

Av. 28 de Setembro, 87 - Fundos - FCM - Terreo

20551-030 Rio de Janeiro - RJ Brazil

Phone: (55 21)2587-6121

Fax: (55 21)2587-6133

cristiane@pesquisador.cnpq.br
Conflict of interest: none Financial source: CNPq and FAPERJ

Received: August 18, 2009

Review: October 21, 2009

Accepted: November 19, 2009

\section{How to cite this article}

Marques DS, Gombar FM, Pereira JLA, Sampaio FJB, Ramos CF. Metabolic programming of lipid profile and reproductive organs weight by leptin treatment on early life. Acta Cir Bras. [serial on the Internet] 2010 Jan-Feb;25(1). Available from URL: http:// www.scielo.br/acb 